\title{
CRUMB BRIQUETTES FOR CONSUMERS WITH THE INCREASED PROTEIN NEEDS
}

\author{
V. Makhynko, V. Drobot, M. Zemlynska \\ National University of Food Technologies
}

\begin{tabular}{l}
\multicolumn{1}{c}{ Key words: } \\
Nutrition \\
Protein \\
Crumb briquettes \\
Technology \\
Briquetting \\
\hline \multicolumn{1}{c}{ Article history: } \\
Received 10.05.2018 \\
Received in revised form \\
23.05.2018 \\
Accepted 15.06.2018 \\
\hline
\end{tabular}

Corresponding author:

V. Makhynko

E-mail:

npnuht@ukr.net

\begin{abstract}
An adequate quantity of protein is a hallmark of a balanced diet. There are legally approved norms of physiological protein needs, which became standard for food industry specialists who are developing new food products or improving existing ones. However, the needs of consumers with low or average level of physical activity are usually taken as a basis. For consumers with high physical activity, the protein need increases by $35 \ldots 45 \%$, which requires the development of special high-protein food.

The article analyzes the protein needs of consumers of $1-5$ physical activity groups, athletes of various sports, and tourists. The necessity of creating bread products containing $1,5 \ldots 2$ times more protein than traditional products is shown. Since the addition of significant amount of an additional raw material can negatively affect the quality of finished products, it was proposed to enrich new product - crumb briquettes made of bread crumbs. According to the requirements for high protein products, the recipes of products containing soy protein isolate and maltodextrin have been selected. Change of the main quality indicators of crumb briquettes (robustness and duration of soaking) depending on the size of the crumb and compacting pressure has been studied. A mathematical description of the increase in the values of the investigated parameters with the increase in the size of the crumb particles and the increase in pressure was obtained. Mathematical modeling allowed to obtain an adequate mathematical model of the compression process and to evaluate the influence of selected factors on the final characteristics of the developed products. The formula and the method of preparation of high-protein crumb briquettes, including $12 \%$ soy protein isolate and $11,6 \%$ maltodextrin, has been offered. The calculation of the nutritional and biological value has confirmed the efficiency of the selected raw materials for the production of high-protein bread products.
\end{abstract}

DOI: $10.24263 / 2225-2924-2018-24-3-19$ 


\title{
СУХАРНІ БРИКЕТИ ДЛЯ СПОЖИВАЧІВ З ПІДВИЩЕНИМИ БІЛКОВИМИ ПОТРЕБАМИ
}

\author{
В.М. Махинько, В.І. Дробот, М.Д. Землинська \\ Національний університет харчових технологій
}

Наявність достатньої кількості білка є однією з визначальних ознак збалансованого рачіону харчування. Існують законодавчо затверджені норми фізіологічних білкових потреб, на які орієнтуються фахівці харчової промисловості, розробляючи нові чи вдосконалюючи існуючі харчові продукти. Однак при цьому за основу, зазвичай, приймають потреби споживачів низького чи середнього рівня фізичної активності. Для споживачів з підвищеними фізичними навантаженнями потреба в білках зростає на $35 \ldots 45 \%$, що вимагає розроблення спеціальних високобілкових харчових продуктів.

У статті проаналізовано білкові потреби споживачів IV-V груп фізичної активності, спортсменів різних видів спорту і туристів. Доведено необхідність створення хлібних виробів, щзо міститимуть у 1,5 ...2 рази більше білка, ніж традиційна продукція. Оскільки внесення значної кількості додатковоі сировини може негативно вплинути на якість готових виробів, запропоновано проводити збагачення новітнього продукту - сухарних брикетів, щчо виготовляються з хлібної крихти. Згідно з вимогами до високобілкових продуктів підібрано рещептури виробів із внесенням ізоляту соєвого білка та мальтодекстину. Вивчено зміну основних показників якості сухарних брикетів (міцності й тривалості розмокання) залежно від крупності крихти й тиску пресування. Одержано математичний опис зростання величин досліджуваних показників зі збільшенням розміру частинок крихти і підвищенням тиску. Проведене математичне моделювання дало змогу отримати адекватну математичну модель процесу пресування та оцінити вплив обраних факторів на кінцеві характеристики розроблених виробів. Запропоновано рещептуру $i$ спосіб приготування високобілкових сухарних брикетів, до складу яких входить 12\% ізоляту соєвого білка та 11,6\% мальтодекстрину. Розрахунок харчової та біологічної цінності підтвердив ефективність використання обраної сировини для одержання високобілкових хлібних виробів.

Ключові слова: харчування, білок, сухарні брикети, технологія, брикетування.

Постановка проблеми. Раціональна організація харчування передбачає надходження з їжею всіх необхідних речовин відповідно до потреб організму, зумовлених його станом і рівнем фізичної активності людини. Особлива роль серед харчових речовин належить білкові, оскільки організм людини не здатен накопичувати значні його запаси, а фізіологічна роль білка $є$ визначальною для повноцінного функціонування практично всіх органів і систем людини. Фахівці харчової промисловості у співпраці 3 науковцями галузі намагаються удосконалювати існуючі та розробляти нові продукти з урахуванням останніх досягнень нутриціології. Основою для подібних розробок $€$ 
законодавчо затверджені «Норми фізіологічних потреб населення України в основних харчових речовинах та енергії» [1]. На жаль, у більшості випадків враховуються білкові потреби споживачів лише I-II груп інтенсивності праці, хоча відомо, що з підвищенням рівня фізичної активності потреби організму в додатковій кількості білка досить суттєво зростають [2; 3]. Аналіз рекомендацій щодо споживання білка, закладених у нові «Норми фізіологічних потреб...» (табл. 1), підтверджує наше припущення: для повноцінного функціонування організму (як чоловічого, так і жіночого) в умовах підвищених фізичних навантажень норма спожитого білка має бути майже у 1,5 раза вища порівняно 3 першим рівнем фізичної активності. Тому доцільним $\epsilon$ розроблення хлібних продуктів з підвищеним вмістом білка, що орієнтовані на фізіологічні потреби споживачів III-IV (а для чоловіків - i V) групи фізичної активності.

Таблиця 1. Норми фізіологічних потреб у білку залежно від статі та рівня фізичної активності

\begin{tabular}{|c|c|c|c|c|c|c|c|c|c|}
\hline Стать & \multicolumn{4}{|c|}{ Чоловіки } & \multicolumn{5}{|c|}{ Жінки } \\
\hline $\begin{array}{c}\text { Група фізичної } \\
\text { активності }\end{array}$ & I & II & III & IV & V & I & II & III & IV \\
\hline Норма споживання білка, г & 80 & 91 & 106 & 108 & 117 & 61 & 66 & 76 & 87 \\
\hline $\begin{array}{c}\text { Зростання відносно } \\
\text { першої групи фізичної } \\
\text { активності, \% }\end{array}$ & - & 13,8 & 33,0 & 35,0 & 46,3 & - & 8,2 & 24,6 & 42,6 \\
\hline
\end{tabular}

Необхідність споживати додаткову кількість білка мають також спортсмени. Адже для більшості видів спорту характерними є навантаження, що за калорійністю (i, відповідно, нормованою кількістю білка) не лише наближаються до потреб споживачів високого рівня фізичної активності, але й перевищують їх (табл. 2) [4; 5].

Таблиця 2. Оріснтовні норми фізіологічних потреб спортсменів різних видів спорту і статі у білках

\begin{tabular}{|c|c|c|}
\hline Група видів спорту & Стать & Норма, г \\
\hline \multirow{2}{*}{ Види спорту, не пов'язані із значними фізичними навантаженнями } & Ж & $96 \ldots 109$ \\
& Ж & $89 \ldots 102$ \\
\hline Види спорту, пов'язані з короткочасними, але значними & ч & $120 \ldots 154$ \\
навантаженнями & Ж & $102 \ldots 136$ \\
\hline Види спорту, що характеризуються великим об'ємом та & ' & $154 \ldots 174$ \\
інтенсивністю фізичного навантаження & Ж & $136 \ldots 158$ \\
\hline Види спорту, пов'язані з тривалими і напруженими & Ч & $174 \ldots 190$ \\
навантаженнями & Ж & $158 \ldots 175$ \\
\hline
\end{tabular}

Як бачимо, навіть максимальні рівні споживання білка, передбачені «Нормами фізіологічних потреб...», $є$ недостатніми майже для всіх категорій спортсменів. У період інтенсивної підготовки до змагань та їх проведення фізіологічні потреби організму спортсмена в білках перевищують рекомендовані для звичайного споживача норми майже у 1,5 раза.

Специфічною формою фізичної активності є туризм. Хоча на сьогодні він нараховує велику кількість різновидів, класичними можна визнати піший, 
гірський і лижний види туризму. Участь у туристичних походах цих типів передбачає тривалі за часом i значні за інтенсивністю навантаження. Тому енерговитрати для маршрутів високої складності можуть сягати 5..6,5 тис. ккал [6]. Прийнявши рекомендовану «Нормами фізіологічних потреб...» частку білка у загальній калорійності раціону для дорослого населення на рівні 13\%, можемо розрахувати приблизні білкові потреби туристів залежно від виду та категорії складності маршруту (табл. 3).

Таблиия 3. Білкові потреби туристів залежно від виду і категорії складності маршруту

\begin{tabular}{|c|c|c|c|c|c|}
\hline \multicolumn{2}{|c|}{$\begin{array}{c}\text { Категорія } \\
\text { складності }\end{array}$} & \multicolumn{2}{|c|}{$\begin{array}{c}\text { Білкові потреби (г) за видом туризму } \\
\text { піший }\end{array}$} & $\begin{array}{c}\text { Зростання відносно } \\
\text { першої категорії } \\
\text { складності, \% }\end{array}$ \\
\hline \multirow{2}{*}{ Низька } & I & 101 & 121 & 131 & - \\
\cline { 2 - 6 } & II & 111 & 133 & 144 & 9,7 \\
\hline \multirow{2}{*}{ Середня } & III & 120 & 144 & 156 & 19,4 \\
\cline { 2 - 6 } & IV & 133 & 160 & 173 & 32,3 \\
\hline \multirow{2}{*}{ Висока } & V & 146 & 176 & 190 & 45,2 \\
\cline { 2 - 5 } & VI & 163 & 195 & 211 & 61,3 \\
\hline
\end{tabular}

Дані табл. 3 свідчать, що потреби в енергї туристів на маршрутах високої категорії складності перевищують норми фізіологічних потреб дорослого населення навіть для V групи фізичної активності та наближаються до енергопотреб спортсменів 3 великим обсягом та інтенсивністю фізичного навантаження. Це підтверджує наше припущення про належність згаданих видів туризму до групи фізичної активності, яка вимагає підвищених рівнів споживання макронутрієнтів (насамперед білка). Однак до туристичного харчування висувається одна специфічна вимога: якомога менший об'єм i маса (зумовлені необхідністю переносити запас харчових продуктів самими туристами), що передбачає високу концентрацію поживних речовин. До того ж такі продукти повинні мати високу харчову цінність і швидко готуватися, що наближає їх до групи харчових концентратів. Певна частина продуктів повинна бути готова до споживання взагалі без кулінарного приготування: особливим видом туристичних харчових продуктів є так зване «кишенькове харчування» - продукти невеликої маси та розміру, що вживаються протягом туристичної мандрівки без зупинки для приготування їжі. Їх калорійність у загальному раціоні може сягати $10 \%$ [6; 7]. Зазвичай, для цього використовують сухофрукти чи льодяникову карамель, однак вказані продукти здатні задовольнити лише вуглеводно-калорійні потреби організму.

Мета дослідження: розроблення високобілкових хлібних виробів 3 високою біологічною та енергетичною цінністю, що можуть бути використані як «кишенькове харчування» у туристичних походах або під час довготривалих спортивних змагань.

Викладення основних результатів дослідження. Більшість традиційних хлібобулочних виробів не відповідають поставленим вимогам: мають недостатню кількість білка низької біологічної цінності, недостатній термін зберігання та значну розпушеність (що зумовлює низьку концентрацію білка в одиниці об’єму). Тому слід звернути увагу на нетрадиційну хлібну продук- 
цію, що може стати основою для подальшого удосконалення рецептур і харчової цінності. До таких виробів можна віднести сухарні брикети, які виготовляють спресовуванням висушеної хлібної крихти 3 додатковою сировиною. Оскільки технологія хлібних брикетів не передбачає стадії бродіння, співвідношення рецептурних компонентів може коливатися у широких межах. Відсутність стадії випікання забезпечить збереження максимальної кількості внесених білкових речовин.

Обирати продукти для збагачення сухарних брикетів білком потрібно 3 урахуванням особливостей подальшої технології. Перевагу слід надавати сипким продуктам без сторонніх присмаку і запаху та 3 високим вмістом білка, що дасть змогу вносити цю сировину без додаткової підготовки і в невеликих кількостях. Також важливо, щоб білок обраної сировини доповнював наявні в хлібній крихті білки за вмістом лімітуючих амінокислот. Усім цим вимогам відповідають ізоляти рослинних білків, які містять до 90\% (на СР) білка, багатого лізином - найдефіцитнішою амінокислотою хлібних виробів 3 пшеничного борошна. Для подальших досліджень обрано ізолят соєвого білка, оскільки він має найнижчу вартість, а амінокислотна формула 3 високим вмістом лізину доповнює білок пшеничного борошна, суттєво підвищуючи харчову та біологічну цінність готових виробів [8].

Як зазначалося, піший туризм характеризується безперервністю чи підвищеною тривалістю навантажень, що наближає його до видів спорту, пов'язаних 3 тривалими і напруженими фізичними навантаженнями - марафонського та лижного бігу, спортивної ходьби тощо. Для забезпечення підвищеної витривалості м'язів важливим $€$ постійне надходження легкозасвоюваних вуглеводів. Дешевим джерелом простих цукрів $є$ патока, однак ії використання в технології сухарних брикетів обмежене високою в’язкістю і складністю точного дозування. 3 цієї точки зору значно перспективнішим видом сировини $\epsilon$ мальтодекстрин, що випускається у вигляді дрібнокристалічного порошку білого кольору і містить близько 94\% швидкозасвоюваних вуглеводів.

Для забезпечення проектованому виробу статусу «високобілковий» було проведено пошук нормативних критеріїв для класифікації білковмісних продуктів. Згідно 3 проектом Закону України «Про інформацію для споживачів щодо харчових продуктів» [9] продуктом з високим вмістом білка може називатися виріб, у якому за рахунок білка забезпечується щонайменше $20 \%$ загальної калорійності продукту. Виходячи з цієї норми і необхідності дотримуватися співвідношення білків і вуглеводів приблизно 1:4, а також враховуючи, що пресуванням можна одержувати вироби з сировини, вміст якої допускається змінювати у широких межах, було проведено комп'ютерне моделювання рецептур високобілкових сухарних брикетів на основі хлібної крихти, ізоляту соєвого білка та мальтодекстрину (табл. 4).

Табличя 4. Варіанти рецептур сухарних брикетів

\begin{tabular}{|c|c|c|c|c|c|c|}
\hline \multirow{2}{*}{ Сировина } & \multicolumn{7}{|c|}{ Bapiaнт } \\
\cline { 2 - 8 } & № 1 & № 2 & № 3 & № 4 & № 5 & № 6 \\
\hline 1 & 2 & 3 & 4 & 5 & 6 & 7 \\
\hline Сухарі пшеничні, Г & 100 & 100 & 100 & 100 & 100 & 100 \\
\hline
\end{tabular}




\begin{tabular}{|c|c|c|c|c|c|c|}
\hline \multicolumn{7}{c}{ Продовження табл. 4 } \\
\hline 1 & 2 & 3 & 4 & 5 & 6 & 7 \\
\hline Ізолят соєвого білка, г & 10 & 11 & 12 & 13 & 14 & 15 \\
\hline Мальтодекстрин, г & 4 & 7,8 & 11,6 & 15,4 & 19,2 & 23 \\
\hline Вміст макронутрієнтів у 100 г суміші, г: & \multicolumn{5}{|c|}{} \\
\hline білки & 17,5 & 17,6 & 17,6 & 17,7 & 17,7 & 17,8 \\
\hline жири & 1,3 & 1,2 & 1,2 & 1,1 & 1,1 & 1,1 \\
\hline вуглеводи & 67,3 & 67,6 & 67,9 & 68,1 & 68,4 & 68,6 \\
\hline
\end{tabular}

Як бачимо, рецептури сухарних брикетів, що відповідають поставленим вимогам, суттєво відрізняються, що впливатиме на якість готових виробів. Тому було проведено системний аналіз технології виготовлення сухарних брикетів, що дало змогу виявити центральну підсистему, на якій формуються основні органолептичні та фізико-хімічні показники сухарних брикетів - це стадія пресування. Оскільки технологія брикетування є характерною для фармацевтичної та харчоконцентратної галузей промисловості, з метою оцінювання якості сухарних брикетів використовували традиційні для цих галузей показники - міцність і тривалість розмочування [10; 11$]$.

На першому етапі вивчали зміну показників якості готових виробів залежно від крупності сухарної крихти. Попередніми дослідженнями було встановлено, що серед представлених на ринку України видів панірувальних сухарів відсутня зіставність гранулометричного складу [12]. Водночас теорія брикетування стверджує, що високу якість пресування можуть забезпечити компоненти, близькі (але не однакові) за фракційним складом. Тому було прийнято рішення готувати крихту для пресування 3 трьох фракцій, підібраних за законом нормального розподілу: основну фракцію брали в кількості 44\% загальної маси, по 28\% припадало на дрібнішу та крупнішу фракції. У подальших дослідженнях використовували чотири партії крихти, де крупність основної фракції відповідала проходу крізь сита: зразок 1 - сито № 0,56, зразок 2 - сито № 1,0, зразок 3 - сито № 1,5, зразок 4 - сито № 2,0. Пресування проводили на гідравлічному пресі, використовуючи матрицю внутрішнім діаметром 20 мм. Маса наважки - 5 г, зважаючи на необхідність забезпечити прийняте у фармацевтичній промисловості оптимальне співвідношення діаметру і висоти як 1:0,5. Пресування проводили при тиску 127 МПа, витримуючи брикет під навантаженням 30 сек.

Встановлено (рис. 1), що зростання крупності крихти призводить до підвищення у $1,3 \ldots 2,4$ раза міцності готових брикетів і подовження тривалості їх розмокання у 6,5..10 разів. Сухарні брикети, виготовлені з найдрібнішої серед досліджуваних фракцій крихти, мали недостатню міцність, що спричиняє часткове руйнування готових виробів ще на етапі виштовхування 3 прес-форми. Водночас брикети, для виготовлення яких використано найкрупнішу фракцію, мають завищені значення досліджуваних показників, що ускладнить їх використання для «кишенькового» харчування. Подібні сухарні брикети можуть бути рекомендовані для додавання у перші та другі обідні страви під час їх приготування. Використовуючи апроксимаційні можливості пакета 
Microsoft Office Excel, було отримано математичний опис залежностей міцності й тривалості розмокання від крупності крихти (формули наведено на рис. 1).

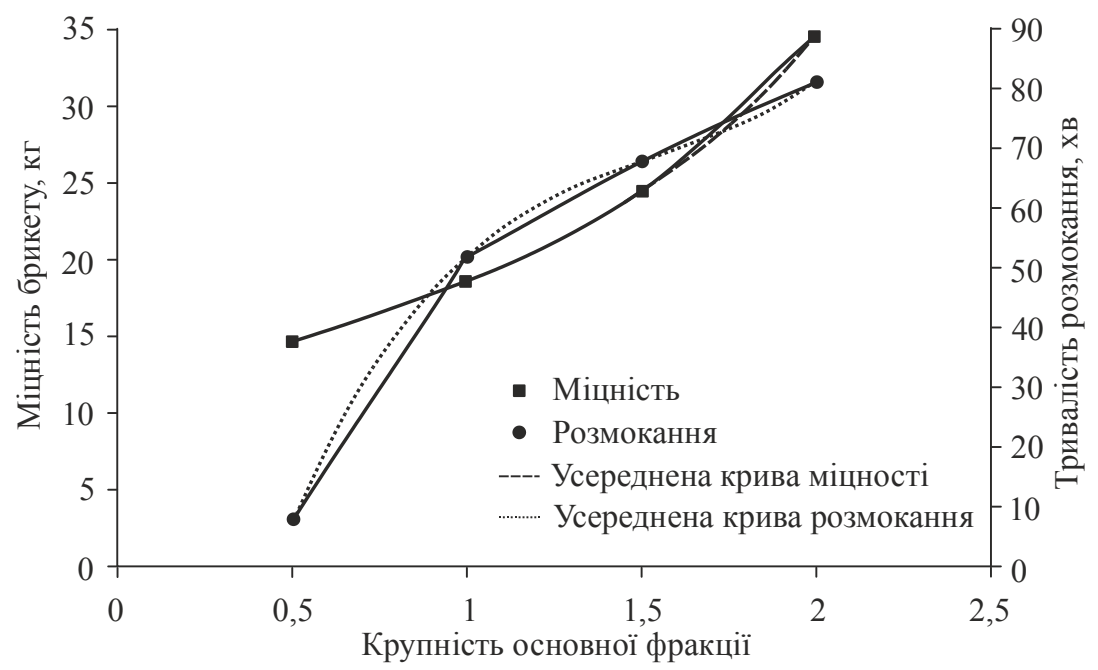

Рис. 1. Міцність і тривалість розмокання сухарного брикету залежно від крупності крихти

На другому етапі досліджень вивчали залежність основних фізико-хімічних показників сухарних брикетів від тиску пресування. Величину тиску змінювали від 127 до 255 МПа. Застосування нижчого тиску, ніж зазначена нижня межа, не забезпечувало спресовування рецептурної суміші, а перевищення верхньої межі підвищувало тиск, необхідний для виштовхування одержаного брикету з матриці, призводячи до його часткового руйнування. Графічний і математичний опис одержаних залежностей наведено на рис. 2.

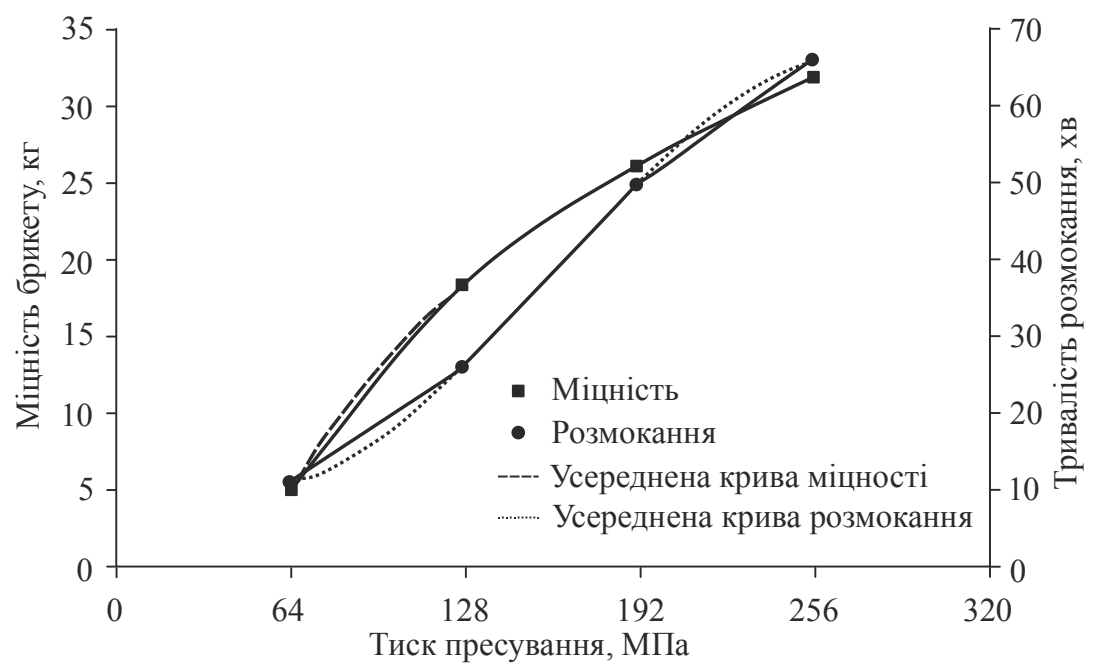

Рис. 2. Міцність і тривалість розмокання сухарного брикету залежно від тиску пресування 
Як бачимо, спостерігається майже прямо пропорційне зростання досліджуваних показників залежно від тиску пресування. Одержані дані можна пояснити ущільненням сухарних брикетів, що підвищує ступінь щеплення частинок між собою, призводячи до зростання міцності готових виробів. Утворення щільного зовнішнього шару ускладнює проникнення вологи у внутрішні частини брикету, а відсутність великих внутрішніх пор перешкоджає швидкій міграції вологи до центру виробу, подовжуючи тривалість його розмокання.

На основі одержаних даних і підібраного співвідношення рецептурних компонентів було проведено математичне моделювання центральної підсистеми технології виготовлення сухарних брикетів - стадії пресування. Зважаючи на невелику кількість вхідних факторів і незначну тривалість дослідження, оптимальним варіантом одержання математичної моделі можна вважати повний факторний експеримент (ПФЕ) $2^{3}$, в якому три досліджувані фактори змінювали лише на двох рівнях: верхньому і нижньому. Оскільки метою дослідження було забезпечення високої харчової цінності готових виробів, за вхідні фактори обрали кількість внесеного ізоляту соєвого білка $\left(G_{\text {iз }}\right)$, крупність крихти $\left(K_{\mathrm{K}}\right)$ і тиск пресування $\left(P_{\text {п }}\right)$ з діапазонами зміни значень, наведеними у табл. 5. За критерій оптимальності обрано міцність брикетів, оскільки цей показник показав кращу повторюваність результатів паралельних визначень і вимагає менше часу для проведення аналізу.

Таблиия 5. Діапазони факторного простору експерименту

\begin{tabular}{|c|c|c|c|}
\hline \multirow{2}{*}{ Рівні факторів } & \multicolumn{3}{|c|}{ Досліджувані фактори } \\
\cline { 2 - 4 } & $\begin{array}{c}\text { Кількість ізоляту } \\
\left(X_{1}\right), \Gamma\end{array}$ & $\begin{array}{c}\text { Крупність } \\
\text { крихти }\left(X_{2}\right)\end{array}$ & $\begin{array}{c}\text { Тиск пресування } \\
\left(X_{3}\right), \text { МПа }\end{array}$ \\
\hline Нульовий рівень & 12 & 0,68 & 191 \\
\hline Інтервал варіювання & 2 & 0,12 & 64 \\
\hline Верхній рівень & 14 & 0,8 & 127 \\
\hline Нижній рівень & 10 & 0,56 & 255 \\
\hline
\end{tabular}

Математико-статистичне опрацювання одержаних значень змінної стану $Y$ дало змогу підтвердити вагомість (суттєвість) обраних вхідних факторів за критерієм Стьюдента та отримати адекватну математичну модель:

$$
Y=15,15+1,38 X_{1}+1,28 X_{2}+1,40 X_{3} .
$$

Аналізуючи коефіцієнти одержаного рівняння, можемо стверджувати, що всі три обраних фактори мають приблизно однаковий позитивний вплив на зростання міцності сухарних брикетів. Також одержана залежність підтверджує наше припущення про визначальний вплив тиску пресування на забезпечення структурних характеристик готових виробів.

Для зручності використання в практичній діяльності та можливості розрахункового прогнозування зміни міцності брикетів у заданому діапазоні досліджуваних факторів опис процесу пресування також представлено в натуральному вигляді:

$$
Y=-4,61+0,69 G_{\mathrm{i3}}+10,7 \mathrm{~K}_{\mathrm{K}}+0,14 P_{\text {п }} \text {. }
$$


На завершальному етапі досліджень проведено розрахунок харчової та біологічної цінності розроблених сухарних брикетів. Для наочності одержані дані порівняно з хімічним складом і біологічною цінністю сухарів вершкових вищого сорту (табл. 6).

Таблиця 6. Харчова і біологічна цінність сухарних брикетів

\begin{tabular}{|c|c|c|c|}
\hline Елемент хімічного складу сировини & $\begin{array}{c}\text { Сухарі } \\
\text { вершкові }\end{array}$ & $\begin{array}{c}\text { Сухарний } \\
\text { брикет }\end{array}$ & $\begin{array}{c}\text { Відхилення, } \\
\%\end{array}$ \\
\hline Білки, г/100 г & 8,5 & 17,6 & $+107,2$ \\
\hline Жири, г/100 г & 10,83 & 1,2 & $-88,9$ \\
\hline Вуглеводи, г/100 г & 69,6 & 67,9 & $-2,4$ \\
\hline Амінокислоти, мг/100 г продукту & \multicolumn{3}{|l|}{} \\
\hline валін & 393 & 852,2 & $+116,8$ \\
\hline ізолейцин & 359 & 859,6 & $+139,4$ \\
\hline лейцин & 668 & 1355,2 & $+102,9$ \\
\hline лізин & 226 & 791,6 & $+250,3$ \\
\hline метіонін+цистин & 302 & 515,9 & $+70,8$ \\
\hline треонін & 269 & 650,4 & $+141,8$ \\
\hline триптофан & 85 & 214,1 & $+151,9$ \\
\hline фенілаланін+тирозин & 628 & 1414,0 & $+125,2$ \\
\hline
\end{tabular}

\section{Висновки}

Наведені у статті дані свідчать про досягнення основної мети - розроблені сухарні брикети містять удвічі більше білка, до того ж його біологічна цінність значно вища за білок хлібної крихти: вміст лімітуючої для виробів 3 пшеничного борошна амінокислоти лізину зріс у 3,5 раза. Вироби мають високі органолептичні та необхідні фізико-хімічні показники, відповідають основним вимогам до «кишенькового» харчування туристів: невелика маса $\mathrm{i}$ об'єм, необхідна міцність, достатня тривалість зберігання (зумовлена низькою вологістю), висока концентрація легкозасвоюваних вуглеводів та біологічно-повноцінного білка.

\section{Література}

1. Наказ про затвердження норм фізіологічних потреб населення України в основних харчових речовинах та енергії (2017), МОЗ України; Наказ від 03.09.2017 № 1073. [Електронний ресурс]. - Режим доступу : http://zakon2.rada.gov.ua/laws/show/z1206-17. — дата звернення 26.03.2018.

2. Wolfe R.R., Cifelli A.M., Kostas G., \& Kim I.Y. (2017). Optimizing Protein Intake in Adults: Interpretation and Application of the Recommended Dietary Allowance Compared with the Acceptable Macronutrient Distribution Range. Advances in Nutrition, 8(2), 266-275.

3. Bilsborough, S., \& Mann, N. (2006). A review of issues of dietary protein intake in humans. International journal of sport nutrition and exercise metabolism, 16(2), 129-152.

4. Пшендин А.И. Рациональное питание спортсменов. Для любителей и профессионалов. - Санкт-Петербург : Олимп-СПб, 2003. - 160 с.

5. Vici, G., Cesanelli, L., Belli, L., Ceci, R., \& Polzonetti, V. (2017). The Impact of Protein Content on Athletes' Body Composition. World Academy of Science, Engineering and Technology, International Journal of Sport and Health Sciences, 4(9), 566.

6. Грабовський Ю.А., Скалій О.В., Скалій Т.В. Спортивний туризм: Навчальний посібник. - Тернопіль : Навчальна книга - Богдан, 2009. - 304 с. 
7. Шимановский В.Ф. Питание в туристическом путешествии / В.Ф. Шимановский, В.Н. Ганопольский. - Москва : Профиздат, 1986. - 176 с.

8. Повноцінне харчування : інноваційні аспекти технологій, енергоефективного виробництва, зберігання та маркетингу : кол. моногр. / за ред. В.В. Євлаш, В.О. Потапова, Н.Л. Савицької ; Харк. держ. ун-т харч. та торг. - Харків : ХДУХТ, $2015-580$ с.

9. Проект закону України «Про інформацію для споживачів щодо харчових продуктів»: (офіц. текст: за станом на 14 березня 2017 р.) / Верховна Рада України. URL: http://w1.c1.rada.gov.ua/pls/zweb2/webproc34?id=\&pf3511=58324\&pf35401=378857 (дата звернення: 26.03.2018).

10. Дмитрієвський Д.І. Технологія лікарських препаратів промислового виробництва / Д.І. Дмитрієвський, Л.І. Богуславська, Л.М. Хохлова // за ред. Д.І. Дмитрієвського. Вінниця : Нова книга, 2008. - 280 с.

11. Рубан О.А. Практикум з промислової технології лікарських засобів / О.А. Рубан, Д.І. Дмитрієвський, Л.М. Хохлова // за ред. Рубан О.А. - Харків : НФаУ, 2015. - 374 с.

12. Махинько В. М. Оценка физических свойств крошки для производства сухарных брикетов / В.М. Махинько, Ф.Г. Самбурський, М.Д. Землинська // Научный взгляд в будущее. - Выпуск 7, Том 1. - Одесса : КУПРИЕНКО С.В., 2017. — С. 68-72. 